\title{
Recovery of Platinum-Group Metals from an Unconventional Source of Catalytic Converter Using Pressure Cyanide Leaching and Ionic Liquid Extraction
}

\author{
SADIA ILYAS (1) ${ }^{1,3}$ and HYUNJUNG KIM ${ }^{1,2,4}$ \\ 1.-Department of Mineral Resources and Energy Engineering, Jeonbuk National \\ University, Jeonju, Jeonbuk 54896, Republic of Korea. 2.-Department of Environment and \\ Energy, Jeonbuk National University, Jeonju, Jeonbuk 54896, Republic of Korea. \\ 3.—e-mail: sadiailyas1@yahoo.com. 4.—e-mail: kshjkim@jbnu.ac.kr
}

The fast depletion of critical metals in natural reserves against their increasing demands in advanced technology application presents the necessity to exploit the end-of-life/waste materials as unconventional resources. Due to a higher accumulation of platinum-group metals (PGMs) in exhausted autocatalytic converters, their recycling through an integrative bio-solvo-chemical technique has been studied. PGMs were efficiently dissolved in bio-cyanide solution produced by Chromobacterium violaceum. The autoclave leaching was optimized in the conditions of temperature, $150^{\circ} \mathrm{C} ; p \mathrm{O}_{2}, 200 \mathrm{psi}$; and time, 120 min, yielding $>90 \%$ PGMs' dissolution. PGMs' separation from cyanide leach liquor was performed using an ionic liquid, Cyphos IL101. Under optimum conditions (i.e., ionic liquid concentration, $0.15 \mathrm{~mol} / \mathrm{L}$; extraction $\mathrm{pH}, 10.4$; and temperature, $25^{\circ} \mathrm{C}$ ), $\mathrm{Pt}$ and $\mathrm{Pd}$ were selectively stripping with $>99 \%$ efficiency in $0.1 \mathrm{~mol} / \mathrm{L}$ (acidic) thiourea and $1.0 \mathrm{~mol} / \mathrm{L}$ $\mathrm{HNO}_{3}$ solution, respectively, leaving $\mathrm{Rh}$ in the raffinate.

\section{INTRODUCTION}

Autocatalytic converters are refractory in nature due to the large mass fraction (on average about 43 wt.\%) of cordierite ceramic $\left(\mathrm{Mg}_{2} \mathrm{Al}_{4} \mathrm{Si}_{5} \mathrm{O}_{18}\right)$ therein. They are usually applied to provide the stable basic skeleton in the honeycomb shape of catalytic converters. ${ }^{1} \mathrm{~A}$ thin porous layer of $\gamma-\mathrm{Al}_{2} \mathrm{O}_{3}$ wash-coated onto cordierite provides an effective surface area for dispersing the active metals for the catalytic conversion of exhausted emissions to their less harmful substance (i.e., $\mathrm{CO}_{2}, \mathrm{~N}_{2}$, and $\mathrm{H}_{2} \mathrm{O}$ ). ${ }^{2,3}$ Due to the exhibition of the desired oxidation performance along with better thermal stability, the platinum-group metals (PGMs, that include $\mathrm{Pt}$, $\mathrm{Pd}$, and $\mathrm{Rh}$ ) have been applied since the inception of automotive catalysts for capturing the gaseous emissions. ${ }^{4,5}$ On average, a total of about $2.0 \mathrm{~g} / \mathrm{kg}$ of catalysts with individual concentration ranges of $0.3-1.0 \mathrm{~g} / \mathrm{kg} \mathrm{Pt}, 0.2-0.8 \mathrm{~g} / \mathrm{kg} \mathrm{Pd}$, and $0.05-0.1 \mathrm{~g} / \mathrm{kg}$

(Received September 29, 2021; accepted December 19, 2021; published online January 12, 2022)
$\mathrm{Rh}$ (depending on the type of the vehicle) is engineered in a new car. ${ }^{6}$ The indispensable role of PGMs in autocatalytic converters are leading to the consumption about $35 \% \mathrm{Pt}$ and over $80 \% \mathrm{Pd}$ and $\mathrm{Rh}$ of their total market demands in $2019 .^{7}$ In recent times, although the COVID-19 outbreak may affect near-term automobile demand, the long-term demands of PGMs will continue to grow unless substituted by other metals. ${ }^{8}$ The soaring demands for PGMs and other industrial applications are therefore challenging to alleviate their supply risks with the limited natural reserves and depletion of high-grade ores. ${ }^{9}$ Henceforth, PGMs' extraction from end-of-life (EoL) materials as unconventional resources like exhausted autocatalytic converters is of paramount interest because their concentration in exhausted catalysts (about a total of $0.1 \mathrm{wt} . \%$ ) is a thousand times higher than that of the primary ores. ${ }^{10,11}$ In parallel, the treatment of EoL materials can significantly reduce the waste volume and lower the economic growth dependency on primary minerals' processing. ${ }^{11}$ 
Due to the refractory nature of catalytic converters, high-temperature smelting for collecting PGMs with iron or copper has been employed. ${ }^{1}$ This process is highly energy-consuming and discharges gaseous emissions, which is followed by the tedious dissolution and separation works resulting in unavoidable losses of PGMs. ${ }^{12}$ Due to this, hydrometallurgical recycling has attracted researchers. ${ }^{13}$ Usually, mineral acids of high concentrations including aqua regia and several additives (i.e., $\mathrm{H}_{2} \mathrm{O}_{2}$ and $\mathrm{Al} / \mathrm{Cu}$ chloride) have been employed for PGM dissolution, ${ }^{1,11,14-16}$ albeit the high reagent consumption, the generation of highly acidic effluents, the instability of PGM extraction, and the low recovery of $\mathrm{Rh}$ have been found to be unsatisfactory. ${ }^{17}$ Recently, biotechnology has emerged as a good alternative with a low carbon footprint in extractive metallurgy from ores; ${ }^{18,19}$ however, it is still in the infancy stage for PGM recycling from refractory materials like autocatalytic converters as they are hard-to-leach noble metals.

PGMs' property to form cyanide complexes has been utilized by some researchers with low efficiency of $\mathrm{Pt}$ and $\mathrm{Pd}$ at about $80-85 \%$, and $\mathrm{Rh}$ at around $70-75 \% .^{20,21}$ To the best of our knowledge, no effective bio-cyanidation-leaching of PGMs has yet been reported except for some simulated chemical leaching with $\mathrm{NaCN}$ instead of using actual biogenic cyanide in the system. Therefore, the investigation of PGMs' bio-cyanidation-leaching from the exhausted autocatalytic converter is imperative. Furthermore, selective recovery of PGMs from cyanide leach liquor by adsorption with activated carbon ${ }^{22-24}$ and reductive precipitation with zinc ${ }^{25}$ has been frequently studied. Activated carbon exhibited poor operating ability due to prolonged adsorption with small sorption capacity and high elution temperature. ${ }^{26}$ Due to the low concentration of PGMs, cementation by Zn-dust seems to be impractical. ${ }^{25}$ Nevertheless, liquidliquid extraction has been recently found to be attractive in precious metal metallurgy due to fast extraction kinetics with high capacity and potential regeneration of organic solvents. Very few extractants have been identified to be suitable for PGM extraction from an alkaline cyanide solution, including "green solvents" ionic liquids. ${ }^{25}$ In recent times, several ionic liquids (e.g., pyridinium, pyrrolidinium, and piperidinium, betainium, and phosphonium) have been applied, ${ }^{27}$ although none of the studies has dealt with biogenic cyanide medium.

In the present study, bio-cyanidation of the exhausted autocatalytic converter was examined using oxidative decarboxylation of glycine for the HCN synthesis during the growth phase of Chromobacterium (C.) violaceum. ${ }^{28,29}$ The ground sample preconditioned with $\mathrm{NaOH}$ solution was leached with different concentrations of biogenic cyanide under elevated temperature and partial oxygen pressure $\left(p \mathrm{O}_{2}\right)$. Further, PGMs' separation from the biocyanide leach liquor was performed with an ionic liquid trihexyl(tetradecyl)phosphonium chloride (Cyphos IL101). It is noteworthy to mention that, due to an excellent and simple regeneration ability of Cyphos IL101, ${ }^{27}$ it was chosen to be used in this study. Further, the effect of ionic liquid concentration, extraction $\mathrm{pH}$, temperature, and behavior of the stripping reagents was examined to optimize the conditions of the liquid-liquid extraction process.

\section{MATERIALS AND METHODS}

\section{Materials}

An amount of $15 \mathrm{~kg}$ of exhausted autocatalytic converters was procured from a supplier in Korea. The procured catalysts were ground to size $~$ $150 \mu \mathrm{m}$ using a locally made pulveriser machine. The ground sample was homogenized before preconditioning in $2.0 \mathrm{~mol} / \mathrm{L} \mathrm{NaOH}$ solution at $90^{\circ} \mathrm{C}$ for $60 \mathrm{~min}$. The preconditioned mass was sent for analysis after a hot water washing and overnight drying in a hot air oven at $80^{\circ} \mathrm{C}$. X-ray fluorescence spectroscopy of the preconditioned mass, which was fed for pressure leaching, yielded the composition of refractory substances to be $\mathrm{Al}_{2} \mathrm{O}_{3} 41.8 \%, \mathrm{MgO}$ $17.4 \%, \mathrm{SiO}_{2} 24.2 \%, \mathrm{CeO}_{2} 5.34 \%, \mathrm{ZrO}_{2} 0.72 \%$, and $\mathrm{TiO}_{2} 0.56 \%$. Fire-assay analysis of the preconditioned sample revealed the PGM contents to be $\mathrm{Pt}$ $756 \mathrm{ppm}, \mathrm{Pd} 367.5 \mathrm{ppm}$, and Rh $170.8 \mathrm{ppm}$. Reagents like $\mathrm{NaOH}$ pellets (Junsei Chemical), hydrochloric acid (Merck), nitric acid (RiedeldeHäen), thiourea (Junsei Chemical), the ionic liquid trihexyl(tetradecyl)phosphonium chloride, namely Cyphos IL101 (Cytec Industries, Canada), and aromatic solvent C10 (SOLVENTIS) were used without further purification.

\section{METHODS}

\section{HCN Synthesis and Bio-Cyanide Production}

A cyanide-producing bacterium, $C$. violaceum DSM30191 ${ }^{\mathrm{T}}$, was maintained in YP-medium (yeast extract $5 \mathrm{~g}$, peptone $10 \mathrm{~g}$, distilled water $1 \mathrm{~L}$ ) at $30^{\circ} \mathrm{C}$. For continuous cyanide production and accumulation, the bioreactor was supplemented with $2.0 \mathrm{~g} / \mathrm{L}$ glycine, $1 \mathrm{~L}$ of YP-medium, and two collectors containing $3.5 \mathrm{~mol} / \mathrm{L} \mathrm{NaOH}$ solutions under an agitation of $300 \mathrm{rpm}$ by magnetic paddles. Aeration under the flow rate of $3 \mathrm{~mL} / \mathrm{s}$ was supplied to the biological system. Then, $12 \mathrm{~mL}$ of pre-grown $C$. violaceum (approximately $10^{6} \mathrm{CFU} / \mathrm{mL}$ ) was inoculated into a bioreactor at $30^{\circ} \mathrm{C}$ without feeding fresh YP-medium for 1 day, and $\mathrm{pH}$ was adjusted at 8.5. After day 1, a fresh YP medium (containing $2.0 \mathrm{~g} / \mathrm{L}$ glycine) was fed continuously at a $1000-\mathrm{mL} /$ day flow rate with a peristaltic pump. The reaction volume was constantly maintained at $1 \mathrm{~L}$ with a 1-day hydraulic retention time, and the reactor was operated for 16 days. After periodic sample collection from the bioreactor and the cyanide 
accumulation reactors (bottles), the same volume of fresh $\mathrm{NaOH}$ solution was added to maintain the total reaction volume. Counts of viable cells were carried out by the drop plate method of serial dilution on nutrient agar. The plates were incubated for $24 \mathrm{~h}$ at $30^{\circ} \mathrm{C}$. The cyanide concentration was analyzed by titration against a standard $\mathrm{AgNO}_{3}$ solution. After 16 days of cyanide entrapped in $\mathrm{NaOH}$ solution, a total of $5.8 \mathrm{~g} / \mathrm{L} \mathrm{NaCN}$ was obtained in the solution of $\mathrm{pH}$ 11.6. This biogenic cyanide solution was used as the lixiviant medium for PGM dissolution by autoclave leaching under high pressure and temperature.

\section{Autoclave Leaching for PGMs' Dissolution}

Pressure leaching studies of the preconditioned sample were conducted in a 500-mL Parr autoclave with a (Ni-Cr) Alloy 600 reactor, a variable speed stirrer equipped with two axial impellers with 6 blades, and a controller outside along with an internally mounted cooling coil. Then, a 40-g sample in $200 \mathrm{~mL}$ of the biogenic cyanide solution of a predetermined concentration was charged in the reactor under the fixed agitation speed of 200 rpm and duration of $1 \mathrm{~h}$, while the temperature, pressure, and $\mathrm{NaCN}$ concentration were varied. To vary the $\mathrm{NaCN}$ concentration, the duration of the biocyanidation process was accordingly adjusted along with maintaining $\mathrm{pH} 11.6$ as invariable. The oxygen pressure was maintained by externally supplying the industrial-grade $\mathrm{O}_{2}$ after reaching the desired temperature and considering the in situ pressure at that temperature. At the end of the experiment, the oxygen supply was stopped, and the autoclave was water-cooled. Then, the solution was filtered using a $0.45-\mu \mathrm{m}$ membrane filter, collecting the filtrate for PGM analysis using inductively coupled plasma-mass spectrometry (ICP-MS; MSS 01; SPECTRO Analytical Instruments, Germany). The leaching efficiency of the metals was calculated by:

$$
\text { Leaching }(\%)=\left(\frac{\mathrm{M}_{\mathrm{LL}}}{\mathrm{M}_{\mathrm{IS}}}\right) \times 100
$$

where $\mathrm{M}_{I S}$ and $\mathrm{M}_{\mathrm{LL}}$ are the metal contents in the solid sample and leach liquor, respectively.

\section{PGMs' Separation from Leach Liquor}

Liquid-liquid separation studies were performed in $20-\mathrm{mL}$ vials, wherein equal volumes $(6 \mathrm{~mL})$ of leach liquor and $0.15 \mathrm{~mol} / \mathrm{L}$ ionic liquid solution (otherwise varied in the range of $0.01-0.15 \mathrm{~mol} / \mathrm{L}$ concentration) were equilibrated at $25 \pm 1^{\circ} \mathrm{C}$ for $10 \mathrm{~min}$. Both phases were settled by centrifugation for $3 \mathrm{~min}$, and then the raffinate was carefully withdrawn to analyse the PGM concentration using ICP-MS. As per the analysis of the raffinate, the distribution ratio $(D)$ of the metal was calculated as:

$$
D=\frac{\mathrm{CE}_{\text {org }}}{\mathrm{CE}_{\mathrm{aq}}}
$$

where $\mathrm{CE}_{\text {org }}$ and $\mathrm{CE}_{\mathrm{aq}}$ are the post-extraction metal concentration in the organic and aqueous phases, respectively. Using the $D$ value, the extraction efficiency (in \%) was determined as:

$$
\text { Extraction }(\%)=\frac{D \times\left(\frac{\mathrm{V}_{\text {org }}}{\mathrm{V}_{\text {aq }}}\right)}{D \times\left(\frac{\mathrm{V}_{\text {org }}}{\mathrm{V}_{\text {aq }}}\right)+1} \times 100
$$

where $\mathrm{V}_{\text {org }}$ and $\mathrm{V}_{\mathrm{aq}}$ are the volumes of the organic and aqueous phases, respectively.

Further, the stripping of $\mathrm{Pt}$ and $\mathrm{Pd}$ from the loaded ionic liquid was performed by contact with the pre-determined concentration of stripping solutions at an O:A of $1: 1$, temperature $25 \pm 1^{\circ} \mathrm{C}$, and contact time of $10 \mathrm{~min}$. after the phase separation. The stripping efficiency was calculated as:

$$
\text { Stripping }(\%)=\frac{\mathrm{CS}_{\mathrm{aq}} \times \mathrm{V}_{\mathrm{aq}}}{\mathrm{CS}_{\text {org }} \times \mathrm{V}_{\text {org }}} \times 100
$$

where $\mathrm{CS}_{\text {org }}$ and $\mathrm{CS}_{\mathrm{aq}}$ are the post-stripping metal concentrations in the organic and aqueous phases, respectively.

\section{RESULTS AND DISCUSSION}

\section{Pressure Leaching in Bio-Cyanide Solution}

\section{Effect of Temperature}

Temperature has a direct relationship with pressure for the enhancement of the rate of reaction. ${ }^{30}$ Hence, pressure leaching of PGMs using a biogenic cyanide lixiviant was first investigated at different temperatures elevated in the range of $100-200^{\circ} \mathrm{C}$, while keeping the other parameters constant (NaCN concentration, $5.8 \mathrm{~g} / \mathrm{L} ; p \mathrm{O}_{2}, 150 \mathrm{psi}$; initial $\mathrm{pH}, 11.6$; and time, $60 \mathrm{~min})$. The results shown in

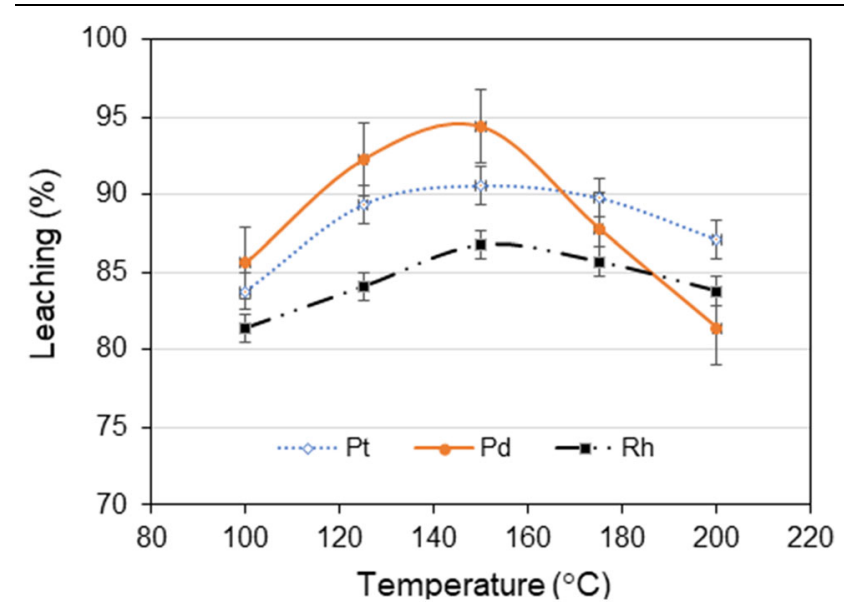

Fig. 1. Effect of temperature on pressure leaching behavior of PGMs from $\mathrm{NaOH}$-preconditioned autocatalytic converter at $\mathrm{NaCN}$ concentration, $5.8 \mathrm{~g} / \mathrm{L} ; \mathrm{pO}_{2}, 150 \mathrm{psi}$; bio-cyanide solution $\mathrm{pH}, 11.6$; and time, $60 \mathrm{~min}$. 
Fig. 1 depict a positive effect of temperature on PGM dissolution. As can be seen, at the elevated temperature of $100^{\circ} \mathrm{C}$ and oxygen pressure of 150 psi, PGM dissolution in the cyanide solution was not more than $85 \%$. An increasing trend of metal dissolution can be ascribed to the physical phenomenon of increased collisions between the particles of the heterogeneous system. ${ }^{30,31}$ Dissolution efficiency reached the maximum of $91 \% \mathrm{Pt}, 94 \% \mathrm{Pd}$, and $87 \% \mathrm{Rh}$ at $150^{\circ} \mathrm{C}$; thereafter, increasing temperature showed a decline in PGM dissolution (87\% $\mathrm{Pt}, 81 \% \mathrm{Pd}$, and $84 \% \mathrm{Rh}$ at $150^{\circ} \mathrm{C}$ ). Comparatively, $\mathrm{Pt}$ and $\mathrm{Rh}$ dissolution decreased slightly in contrast to a steep decline of $\mathrm{Pd}$, which can be corroborated by the non-stability of $\operatorname{Pd}(\mathrm{CN})_{4}{ }^{2-}$ and by cyanide decomposition at higher temperatures. ${ }^{17}$

\section{Effect of Partial Oxygen Pressure}

For autoclaving, in particular, to dissolve difficult-to-leach metals from a refractory material, the role of pressure becomes crucial to liberate the desired metals into solution. Hence, PGM dissolution in biogenic cyanide was examined at various oxygen pressures in the range of 50-250 psi at a fixed temperature of $150^{\circ} \mathrm{C}$. The results in Fig. 2 depict an increasing trend for PGM dissolution with elevating oxygen pressure in the closed system. Biocyanide leaching of PGMs increases significantly (Pt, $83 \%$ to $94 \%$; $\mathrm{Pd}, 86 \%$ to $>96 \%$; and $\mathrm{Rh}, 76 \%$ to $\sim 90 \%$ ) with a change in $p \mathrm{O}_{2}$ from 50 psi to 250 psi. This behavior can be understood by breaking the surface chemical barrier to attack directly the PGM particles by the biogenic cyanide solution, which enhances the dissolution efficiency. ${ }^{11}$ Moreover, the catalytic role of oxygen in cyanide can also be corroborated by the exhibited behavior through the cyanidation reactions, as given in Eqs. 5-7. ${ }^{17}$ Since the maximum dissolution was achieved with a $p \mathrm{O}_{2}$

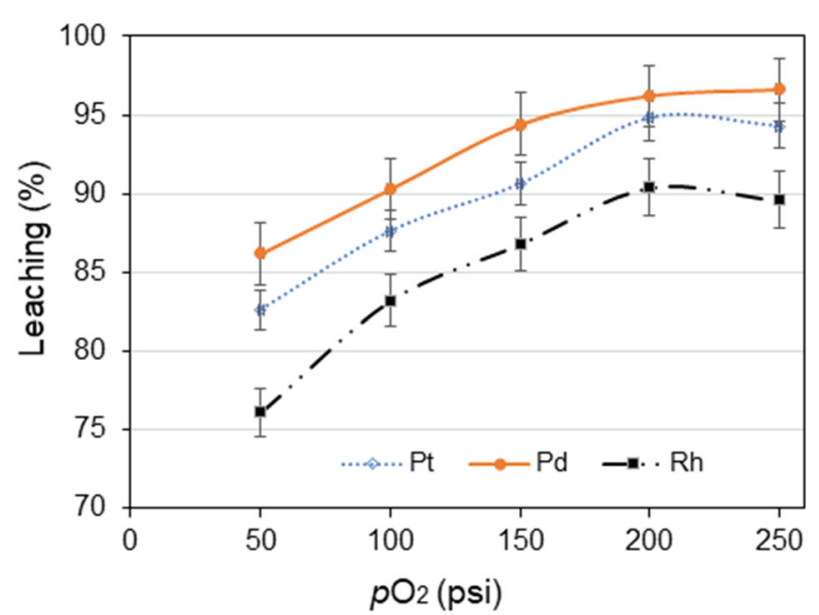

Fig. 2. Effect of oxygen pressure on autoclave leaching of PGMs from $\mathrm{NaOH}$-preconditioned autocatalytic converter at temperature, $150^{\circ} \mathrm{C}$; $\mathrm{NaCN}$ concentration, $5.8 \mathrm{~g} / \mathrm{L}$; bio-cyanide solution $\mathrm{pH}, 11.6$; and time, $60 \mathrm{~min}$. of $200 \mathrm{psi}$, it was maintained throughout the experimental sets.

$$
\begin{aligned}
& 2 \mathrm{Pt}+8 \mathrm{NaCN}+\mathrm{O}_{2}+2 \mathrm{H}_{2} \mathrm{O} \\
& \leftrightarrow 2 \mathrm{Na}_{2}\left[\mathrm{Pt}(\mathrm{CN})_{4}\right]+4 \mathrm{NaOH} \\
& 2 \mathrm{Pd}+8 \mathrm{NaCN}+\mathrm{O}_{2}+2 \mathrm{H}_{2} \mathrm{O} \\
& \leftrightarrow 2 \mathrm{Na}_{2}\left[\mathrm{Pd}(\mathrm{CN})_{4}\right]+4 \mathrm{NaOH} \\
& 4 \mathrm{Rh}+24 \mathrm{NaCN}+3 \mathrm{O}_{2}+6 \mathrm{H}_{2} \mathrm{O} \\
& \leftrightarrow 4 \mathrm{Na}_{3}\left[\mathrm{Rh}(\mathrm{CN})_{6}\right]+12 \mathrm{NaOH}
\end{aligned}
$$

\section{Effect of NaCN Concentration}

To form the PGM cyanide, the optimization of the cyanide concentration for driving Eqs. 5-7 was carried out in the range of $0.63-6.43 \mathrm{~g} / \mathrm{L} \mathrm{NaCN}$ at a constant temperature $\left(150^{\circ} \mathrm{C}\right)$ and $p \mathrm{O}_{2}(200 \mathrm{psi})$. As shown in Fig. 3, PGM dissolution progressed with increasing cyanide concentration as the lixiviant medium. Bio-cyanide leaching of PGMs changed significantly (Pt, from $73 \%$ to $>95 \%$; $\mathrm{Pd}$, from $82 \%$ to $96 \%$; and $\mathrm{Rh}$, from $68 \%$ to $~ 91 \%$ ) with $\mathrm{NaCN}$ concentration from $0.63 \mathrm{~g} / \mathrm{L}$ to $6.43 \mathrm{~g} / \mathrm{L}$. This change in the PGM dissolution behavior indicates a change in the rate mechanism from diffusion-controlled at low cyanide concentration to the chemically-controlled at higher cyanide in solution. ${ }^{11,30,31}$ The maximum leaching efficiency $(\mathrm{Pt}, 157.5 \mathrm{mg} / \mathrm{L}$; $\mathrm{Pd}, 77.6 \mathrm{mg} / \mathrm{L}$; and $\mathrm{Rh}, 33.9 \mathrm{mg} / \mathrm{L}$ ) was achieved at $5.82 \mathrm{~g} / \mathrm{L}$ NaCN solution captured through the microbial-driven HCN synthesis. Thus, this concentration was consider optimum to generate the stock leach liquor for subsequent recovery studies using an ionic liquid (Cyphos IL101).

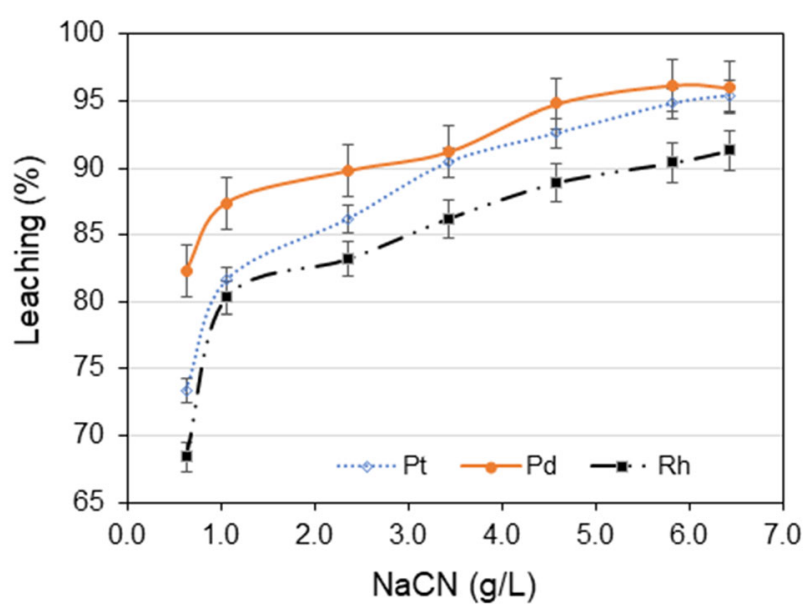

Fig. 3. Effect of $\mathrm{NaCN}$ concentration on pressure leaching of PGMs from $\mathrm{NaOH}$-preconditioned autocatalytic converter at temperature, $150^{\circ} \mathrm{C} ; \mathrm{pO}_{2}, 200 \mathrm{psi}$; bio-cyanide solution $\mathrm{pH}, 11.6$; and time, 60 min. 


\section{PGM SEPARATION FROM LEACH LIQUOR USING IONIC LIQUID}

\section{Effect of Ionic Liquid Concentration}

To study the extraction behavior of PGM' cyanide complexes with the phosphonium-based ionic liquid, Cyphos IL101, further experiments were conducted in the concentration range of $0.01-0.15 \mathrm{~mol} / \mathrm{L}$ Cyphos IL101 prepared in aromatic solvent C10. Other parameters like the O:A phase ratio (1:1), contact time $(10 \mathrm{~min})$, and temperature $\left(25^{\circ} \mathrm{C}\right)$ were kept constant while contacting the leach liquor of $\mathrm{pH}$ 10.8. Figure 4 shows that $\mathrm{Pt}$ and $\mathrm{Pd}$ extraction increased with more active molecules of ionic liquid in the organic phase, leaving all the $\mathrm{Rh}$ in the aqueous raffinate. The shifting of distribution curves with the availability of more extraction sites during the contact of two different phases can be corroborated by the increasing extraction of $\mathrm{Pt}$ and $\mathrm{Pd}^{32,33}$ However, the selectivity for $\mathrm{Rh}$ remaining non-extractable in the raffinate can be related to the geometrically octahedral structure of $\operatorname{Rh}(\mathrm{CN})_{6}{ }^{3-}$ in comparison to the square planar structure of $\mathrm{Pt}(\mathrm{CN})_{4}{ }^{2-}$ and $\mathrm{Pd}(\mathrm{CN})_{4}{ }^{2-}$ complexes. ${ }^{17}$ The extraction of Pt and Pd with Cyphos IL101 can be written as Eqs. 8 and 9. As can be seen, the extraction efficiency of $\mathrm{Pt}$ and $\mathrm{Pd}$ improved from approximately $23 \%$ to $97 \%$ and $<18 \%$ to $94 \%$ with increasing concentration of ionic-liquid from 0.01 $\mathrm{mol} / \mathrm{L}$ to $0.15 \mathrm{~mol} / \mathrm{L}$, respectively. Hence, a concentration $0.15 \mathrm{~mol} / \mathrm{L}$ Cyphos IL101 was optimized to use in the next sets of experiments.

$$
\begin{aligned}
\mathrm{Pt}(\mathrm{CN})_{4}^{2-}+2 \overline{\left[\mathrm{P}_{66614}\right]^{+} \mathrm{Cl}^{-}} \leftrightarrow & \overline{\left(\left[\mathrm{P}_{66614}\right]^{+}\right)_{2} \mathrm{Pt}(\mathrm{CN})_{4}^{2-}} \\
& +2 \mathrm{Cl}^{-}
\end{aligned}
$$

$$
\begin{aligned}
\mathrm{Pd}(\mathrm{CN})_{4}^{2-}+2 \overline{\left[\mathrm{P}_{66614}\right]^{+} \mathrm{Cl}^{-}} \leftrightarrow & \overline{\left(\left[\mathrm{P}_{66614}\right]^{+}\right)_{2} \mathrm{Pd}(\mathrm{CN})_{4}^{2-}} \\
& +2 \mathrm{Cl}^{-}
\end{aligned}
$$

\section{Effect of Leach Liquor $\mathbf{p H}$}

To evaluate the effect of $\mathrm{pH}$ on PGM extraction, the $\mathrm{pH}$ value of the leach liquor was varied from 9.6 to 11.2 while contacting with $0.15 \mathrm{~mol} / \mathrm{L}$ ionic liquid solution at an O:A ratio of 1 . Figure 5 depicts an increasing trend with $\mathrm{Pt}$ and $\mathrm{Pd}$ extraction by decreasing the $\mathrm{pH}$ of the leach liquor from 11.2 $(96.4 \% \mathrm{Pt}$ and $92.7 \% \mathrm{Pd})$ to $10.4(98.2 \% \mathrm{Pt}$ and $97.6 \% \mathrm{Pd}$ ). Thereafter, the extraction efficiency was unchanged up to the leach liquor's $\mathrm{pH}$ of 9.6. A lower extraction at the higher alkaline $\mathrm{pH}$ of leach liquor was probably caused by the competitive extraction of $\mathrm{OH}^{-}$ions. ${ }^{34}$ To prevent the toxicity of HCN at lower $\mathrm{pH},{ }^{28}$ the extraction at $\mathrm{pH} 10.4$ was found to be quantitative and was optimized for subsequent experiments.

\section{Effect of Temperature}

PGM extraction with ionic liquid Cyphos IL101 was evaluated at different temperatures between $25^{\circ} \mathrm{C}$ and $55^{\circ} \mathrm{C}$ while contacting the two phases at an O:A phase ratio of $1: 1$. Figure 6 a shows declining extractions from $98 \%$ to $<90 \% \mathrm{Pt}$ and $\sim 97 \%$ to $87 \%$ $\mathrm{Pd}$ with respect to increasing temperature from $25^{\circ} \mathrm{C}$ to $55^{\circ} \mathrm{C}$. This behavior, indicative of the exothermic process, reveals that the ability of metal-binding sites of Cyphos IL101 is destroyed with the increasing temperature. ${ }^{35,36}$ In the above sets of experiments, Rh was not extracted in the organic phase.

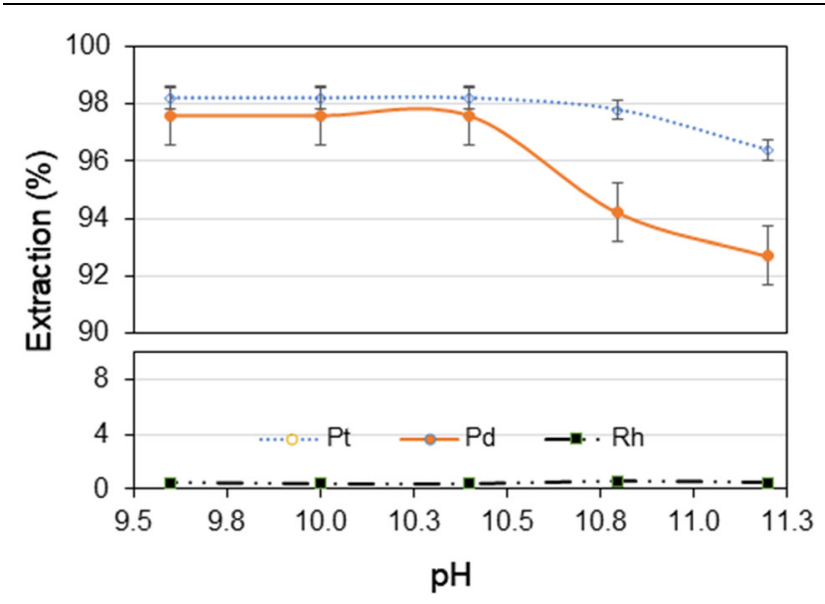

Fig. 5. Effect of leach liquor $\mathrm{pH}$ on PGM extraction at an O:A, 1; ionic liquid concentration, $0.15 \mathrm{~mol} / \mathrm{L}$; contact time, $10 \mathrm{~min}$; and temperature, $25^{\circ} \mathrm{C}$.
Fig. 4. Effect of ionic liquid concentration on $P G M$ extraction from

cyanide leach liquor at an $\mathrm{O}: \mathrm{A}, 1$; leach liquor $\mathrm{pH}, 10.8$; contact time, $10 \mathrm{~min}$; and temperature, $25^{\circ} \mathrm{C}$.

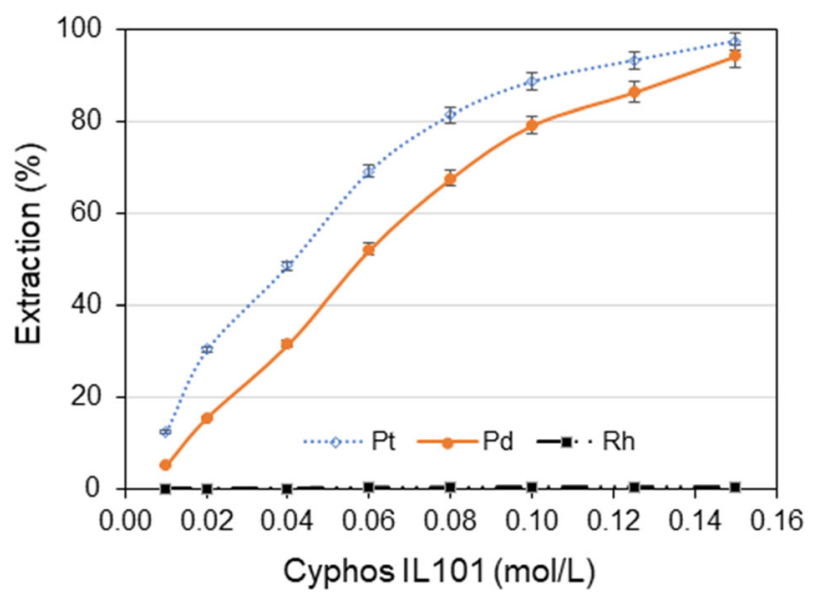




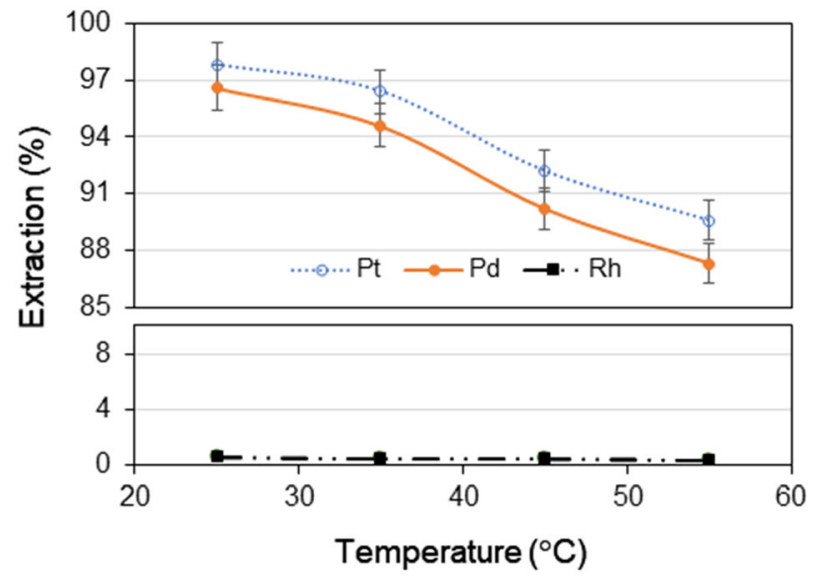

Fig. 6. Effect of temperature on PGM extraction from the cyanide leach liquor with the extraction performed at an $\mathrm{O}: \mathrm{A}, 1$; ionic-liquid concentration, $0.15 \mathrm{~mol} / \mathrm{L}$; leach liquor $\mathrm{pH}, 10.8$; and contact time, 10 $\min$.

\section{Selective Stripping of Pt and Pd from Loaded Ionic Liquid}

The Pt- and Pd-loaded ionic liquid was subjected to selective stripping to achieve their value-added products' high purity from the recycling process. In this context, two different reagents were chosen to investigate the stripping behaviour of the metals. The solutions of $0.1 \mathrm{~mol} / \mathrm{L} \mathrm{CH}_{4} \mathrm{~N}_{2} \mathrm{~S}$ (prepared in 0.5 $\mathrm{mol} / \mathrm{L} \mathrm{HCl}$ ) and $1.0 \mathrm{~mol} / \mathrm{L} \mathrm{HNO}_{3}$ were separately contacted with the loaded organic phase at an O:A of 1 , contact time of $10 \mathrm{~min}$, and $25^{\circ} \mathrm{C}$. The results are shown in Fig. 7, which reveals the possible selective stripping of $\mathrm{Pt}$ and $\mathrm{Pd}$. Stripping with thiourea (refer to Fig. 7a) shows that $\sim 92 \%$ Pd recovery in aqueous solution can be achieved in one step of contact, which accumulatively reached $>99 \%$ after two steps of stripping along with $1.4 \%$ of Pt. In the case of stripping with nitric acid (refer to Fig. 7b), $\mathrm{Pt}$ was selectively stripped back in acidic solution, albeit with only $73 \%$ efficacy. Therefore, the quantitative stripping of $\mathrm{Pt}$ was investigated in 3 steps for an accumulative efficiency of $\sim 99 \%$. In this manner, the separation between $\mathrm{Pt}$ and Pd could be achieved by stripping of the co-extracted loaded ionic liquid phase.

\section{CONCLUSION}

An efficient recycling of a postconsumer refractory material (i.e., exhausted autocatalytic converter) has been studied for PGM recovery by applying an integrative bio-solvo-chemical approach. In order to liberate the PGM particles from the refractory matrix, a $\mathrm{NaOH}$-preconditioned sample was used for the pressure leaching with a biogenic cyanide solution of $\mathrm{NaCN}$ produced through HCN synthesis during the growth phase of $C$. violaceum. The pressure autoclave leaching of PGMs with the biogenic cyanide solution yielded the
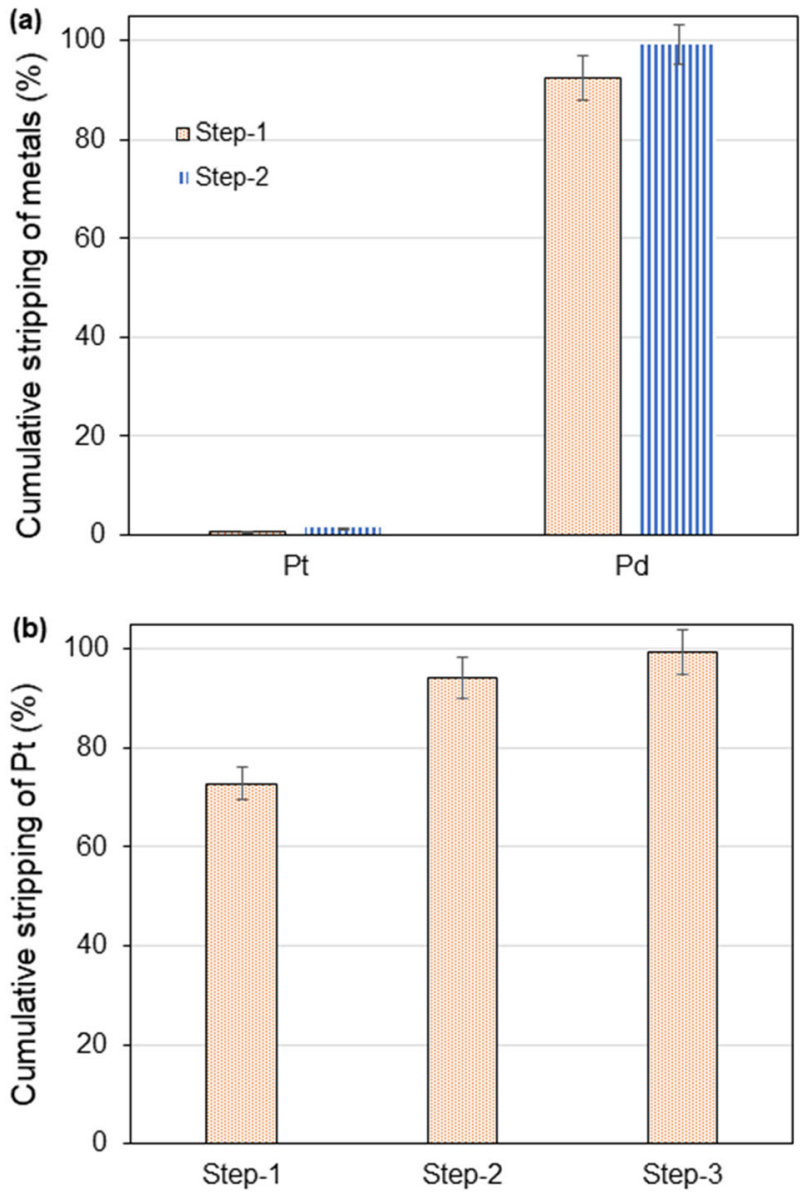

Fig. 7. Stepwise stripping behavior of metals from a loaded ionic liquid phase with $0.1 \mathrm{~mol} / \mathrm{L}$ thiourea prepared in $0.5 \mathrm{~mol} / \mathrm{L} \mathrm{HCl}$ (a) and stripping of Pt from Pd-depleted ionic liquid with $1.0 \mathrm{~mol} / \mathrm{L} \mathrm{HNO}$ (b) at an O:A, 1; contact time, $10 \mathrm{~min}$; and temperature, $25^{\circ} \mathrm{C}$.

maxima of $91 \% \mathrm{Pt}, 94 \% \mathrm{Pd}$, and $87 \% \mathrm{Rh}$ at $150^{\circ} \mathrm{C}$, which remarkably increased with $\mathrm{pO}_{2} 250$ psi (94\% $\mathrm{Pt},>96 \% \mathrm{Pd}$, and $\sim 90 \% \mathrm{Rh})$ and $5.82 \mathrm{~g} / \mathrm{L} \mathrm{NaCN}$ concentration in the biogenic solution. Thereafter, PGM separation from the pressure-leached liquor was demonstrated with an ionic liquid, Cyphos IL101. Selective extraction of $\mathrm{Pt}$ and Pd over Rh was achieved under the optimum conditions of $0.15 \mathrm{~mol} /$ L Cyphos IL101 with initial leach liquor $\mathrm{pH} 10.4$ and temperature of $25^{\circ} \mathrm{C}$. Further, the separation of $\mathrm{Pt}$ and Pd was achieved by the selective stripping of loaded ionic liquid using thiourea and nitric acid solutions. A solution of $0.1 \mathrm{~mol} / \mathrm{L} \mathrm{CH}_{4} \mathrm{~N}_{2} \mathrm{~S}$ (prepared in $0.5 \mathrm{~mol} / \mathrm{L} \mathrm{HCl}$ ) was contacted in two steps followed by contacting the Pd-depleted organic phase with $1.0 \mathrm{~mol} / \mathrm{L} \mathrm{HNO}_{3}$ in three steps which could recover $>99 \% \mathrm{Pt}$ and $\mathrm{Pd}$, respectively. The process essentially contributes to the establishing of an efficient recycling of PGMs coupled with their circular economy to provide an unconventional route of economic development than that by using the primary resources alone. 


\section{ACKNOWLEDGEMENTS}

This work was supported by Basic Science Research Program through the National Research Foundation of Korea (NRF) funded by the Ministry of Education (Project No. 2020R1I1A1A01074249).

\section{CONFLICT OF INTEREST}

The authors declare that they have no conflict of interest.

\section{REFERENCES}

1. S. Ilyas, R.R. Srivastava, H. Kim, and H.A. Cheema, Sep. Purif. Technol. 248, 117029 (2020).

2. M.P. Singh, and S. Raj, IJSER 7, 927 (2016).

3. E.S. Lox, Automotive exhaust treatment, in Handbook of Heterogeneous Catalysis. ed. by G. Ertl, H. Knözinger, F. Schüth, and J. Weitkamp (Wiley, Weinheim, 2008), p. 2274.

4. A. Russell, and W.S. Epling, Catal. Rev. 53, 337 (2011).

5. M.V. Twigg, Catal. Today 117, 407 (2006).

6. H.B. Trinh, J. Lee, Y. Suh, and J. Lee, Waste Manag. 114, $148(2020)$.

7. Johnson Matthey PGM Market Report. (2020). http://www. platinum.matthey.com/services/market-research/pgm-mark et-reports Accessed from 26 Apr 2020.

8. N. Jonson and F. Warwick, Palladium, rhodium demand to remain, despite virus outbreak: analyst. (2021). https://ww w.spglobal.com/platts/en/market-insights/latest-news/metal s/030520-palladium-rhodium-demand-to-remain-despite-vir us-outbreak-analyst Accessed from 28 Apr 2021.

9. KPMG Commodity Insights Bulletin Series, Commodity Insights Bulletin - KPMG Global (home.kpmg). (2015). Accessed from 26 May 2021.

10. S. Steinlechner, and J. Antrekowitsch, PGM recycling from catalysts in a closed hydrometallurgical loop with an optional cerium recovery, in Enabling Materials Resource Sustainability. ed. by A. Kvithyld, C. Meskers, R. Kirchain, G. Krumdick, B. Mishra, M. Reuter, C. Wang, M. Schlesinger, G. Gaustad, D. Lados, and J. Spangenberger (Springer, Cham, 2013), p. 361.

11. S. Ilyas, H. Kim, and R.R. Srivastava, Sustainable Urban Mining of Precious Metals (CRC, Boca Raton, 2021).

12. J. Chen, K. Huang, and Y.R. Chen, South African Patent 2005/05141 (2005).

13. G. Nicol, E. Goosey, D.Ş Yıldız, E. Loving, V.T. Nguyen, S. Riaño, I. Yakoumis, A.M. Martinez, A. Siriwardana, A. Unzurrunzaga, J. Spooren, T.A. Atia, B. Michielsen, X. Dominguez-Benetton, and O. Lanaridi, Johns. Matthey Technol. Rev. 65, 127 (2021).

14. A. Fornalczyk, M. Kraszewski, J. Willner, J. Kaduková, A. Mrážiková, R. Marcinčáková, and O. Velgosová, Arch. Metall. Mater. 61, 233 (2016).
15. C.A. Nogueira, A.P. Paiva, P.C. Oliveira, M.C. Costa, and A.M. Rosa da Costa, J. Hazard. Mater. 278, 82 (2014).

16. S. Steinlechner, and J. Antrekowitsch, JOM 67, 406 (2015),

17. J. Chen, and K. Huang, Hydrometallurgy 82, 164 (2006).

18. S. Ilyas, R. Chi, H.N. Bhatti, I.A. Bhatti, and M.A. Ghauri, Bioprocess. Biosyst. Eng. 35, 433 (2012).

19. J. You, S.K. Solongo, A. Gomez-Flores, S. Choi, H. Zhao, M. Urik, S. Ilyas, and H. Kim, Bioresour. Technol. 307, 123181 (2020).

20. G.B. Atkinson, US Patent 5160711 (1992).

21. D.P. Desmond, High-temperature cyanide leaching of platinum group metals from automobile catalysts - laboratory test. In: Report of Investigations, vol. RI-9384, United States Bureau of Mines (1991).

22. C.A. Snyders, S.M. Bradshaw, G. Akdogan, and J.J. Eksteen, Hydrometallurgy 149, 132 (2014).

23. C.A. Snyders, S.M. Bradshaw, G. Akdogan, and J.J. Eksteen, Miner. Eng. 80, 14 (2015).

24. C.N. Mpinga, S.M. Bradshaw, G. Akdogan, C.A. Snyders, and J.J. Eksteen, Miner. Eng. 55, 11 (2014).

25. C.N. Mpinga, S.M. Bradshaw, G. Akdogan, C.A. Snyders, and J.J. Eksteen, Hydrometallurgy 142, 36 (2014).

26. C. Jin, M. Chen, M. Fan, G. Luo, M. Shao, Z. Huang, and X. Xie, J. Mol. Liq. 336, 116358 (2021).

27. S. Ilyas, H. Kim, and R.R. Srivastava, Sep. Purif. Technol. 248, 119577 (2022)

28. S. Ilyas, and N. Ilyas, Microbial cyanidation of gold, in Gold Metallurgy and the Environment. ed. by S. Ilyas, and J. Lee (CRC, Boca Raton, 2018), p. 157.

29. R.R. Srivastava, S. Ilyas, H. Kim, S. Choi, H.B. Trinh, M.A. Ghauri, and N. Ilyas, J. Chem. Technol. Biotechnol. 95, 2796 (2020).

30. F. Habashi, Principles of Extractive Metallurgy, vol I. (Gordon and Breach, New York, 1969).

31. H. Munir, R.R. Srivastava, H. Kim, S. Ilyas, M.K. Khosa, and B. Yameen, J. Chem. Technol. Biotechnol. 95, 2286 (2020).

32. G.M. Ritcey, and A.W. Ashbrook, Solvent Extraction Part I (Elsevier, Amsterdam, 1984).

33. R.R. Srivastava, S. Ilyas, H. Kim, N.L.M. Tri, N. Hassan, M. Mudassir, and N. Talib, JOM 72, 839 (2020).

34. Z.Y. Wang, Y. Sun, N. Tang, C.L. Miao, Y.T. Wang, L.H. Tang, S.X. Wang, and X.J. Yang, Sep. Purif. Technol. 222, 136 (2019).

35. V.S. Kislik, Solvent Extraction: Classical and Novel Approaches (Elsevier, Amsterdam, 2012).

36. S. Ilyas, H. Kim, and R.R. Srivastava, JOM 73, 19 (2021).

Publisher's Note Springer Nature remains neutral with regard to jurisdictional claims in published maps and institutional affiliations. 